Article

\title{
A Novel Dye-Sensitized Solar Cell Structure Based on Metal Photoanode without FTO/ITO
}

\author{
Jianjun Yang ${ }^{1, *} \mathbb{1}$, Xiaobao $\mathrm{Yu}^{2}$, Yaxin $\mathrm{Li}^{2}$, Guilin Cheng ${ }^{2}$, Zichuan $\mathrm{Yi}^{1}{ }^{1}{ }^{\mathbb{D}}$, Zhi Zhang ${ }^{1}$, Feng Chi ${ }^{1}$ \\ and Liming Liu ${ }^{1}$
}

1 College of Electron and Information, University of Electronic Science and Technology of China, Zhongshan Institute, Zhongshan 528402, China; yizichuan@163.com (Z.Y.); zz001@zsc.edu.cn (Z.Z.); chifeng@semi.ac.cn (F.C.); liulmxps@126.com (L.L.)

2 School of Optoelectronic Science and Engineering, University of Electronic Science and Technology of China, Chengdu 610054, China; yuxiaobao16@126.com (X.Y.); leiyafangzhou@163.com (Y.L.); m13018210687_1@163.com (G.C.)

* Correspondence: sdyman@uestc.edu.cn; Tel.: +86-0760-8831-4612

Citation: Yang, J.; Yu, X.; Li, Y.; Cheng, G.; Yi, Z.; Zhang, Z.; Chi, F.; Liu, L. A Novel Dye-Sensitized Solar Cell Structure Based on Metal Photoanode without FTO/ITO. Micromachines 2022, 13, 122. https:// doi.org/10.3390/mi13010122

Academic Editors: Eui-Hyeok Yang, Zebing Mao, Jin Xie and Hong Ding

Received: 17 December 2021

Accepted: 11 January 2022

Published: 13 January 2022

Publisher's Note: MDPI stays neutral with regard to jurisdictional claims in published maps and institutional affiliations.

Copyright: () 2022 by the authors. Licensee MDPI, Basel, Switzerland. This article is an open access article distributed under the terms and conditions of the Creative Commons Attribution (CC BY) license (https:// creativecommons.org/licenses/by/ $4.0 /)$.

\begin{abstract}
Traditional dye-sensitized solar cells (DSSC) use FTO/ITO containing expensive rare elements as electrodes, which are difficult to meet the requirements of flexibility. A new type of flexible DSSC structure with all-metal electrodes without rare elements is proposed in this paper. Firstly, a light-receiving layer was prepared outside the metal photoanode with small holes to realize the continuous oxidation-reduction reaction in the electrolyte; Secondly, the processing technology of the porous titanium dioxide $\left(\mathrm{TiO}_{2}\right)$ film was analyzed. By testing the $\mathrm{J}-\mathrm{V}$ characteristics, it was found that the performance is better when the heating rate is slow. Finally, the effects of different electrode material combinations were compared through experiments. Our results imply that in the case of all stainless-steel electrodes, the open-circuit voltage can reach $0.73 \mathrm{~V}$, and in the case of a titanium photoanode, the photoelectric conversion efficiency can reach $3.86 \%$.
\end{abstract}

Keywords: DSSC; stainless steel; titanium; titanium dioxide; metal photoanode

\section{Introduction}

In recent years, metal and metal compound electrodes have been extensively studied in DSSC. However, due to their opacity, most of them are limited to the use of a single metal electrode [1-6]. Electrode cost is a problem in the research of photoanodes and counter electrodes (CE) [7,8]. The typical metal mesh electrode technology has not yet been industrialized, and its insufficient light-receiving layer area and complex process of $\mathrm{TiO}_{2}$ film are both limiting factors [9-11].

The photoanode in DSSC should have the functions to adsorb dyes [12] and transmit and collect photogenerated electrons. A good photoanode should have a large specific surface area and a nanoporous structure, which can absorb dyes to the maximum and transmit photogenerated electrons quickly, and have sufficient porosity to penetrate the electrolyte [13-15]. Because $\mathrm{TiO}_{2}$ is nontoxic, cheap, and has strong ability to adsorb dyes [16,17] and transfer electrons [18], it is widely used in the fabrication of photoanodes [19-25]. The introduction of special nanoparticles into a $\mathrm{TiO}_{2}$ matrix can improve the performance of DSSCs, such as adding nanodiamonds (NDs) and CdTe nanoparticles $[26,27]$, but the scarcity of materials will increase production costs. The importance of CE lies in its high catalytic activity [28], such as the catalytic reduction of $I_{3}^{-}$[29]. By using $\mathrm{Pt}$ to reduce the oxidation-reduction potential of the $I_{3}^{-} / I_{1}^{-}$ion pair, it helps to increase the open-circuit voltage [30-33]. Compared with CE based on $\mathrm{Pt}$, the optimized NDs layer has 78.52\% equivalent performance [34]. The traditional sandwich DSSC uses expensive FTO electrodes, which reduce the cost performance, and at the same time, due to its rigidity, the battery loses its flexibility. As for the back-illuminated structure [35], light needs to 
pass through the $\mathrm{CE}$ and electrolyte before reaching the photoanode, and its efficiency is naturally limited [36]. The metal mesh used as CE can replace the transparent conductive film, but the incident light loss caused by the mesh cannot be ignored [37].

In this paper, cheap metal materials (stainless steel and titanium) are used to replace expensive rare-element electrodes to produce photoanode and CE substrates. The photoanode is prepared on the outside of the stainless steel/titanium substrate to enhance light absorption. The electrolyte passes through the photoanode with the light-receiving layer through specially designed small holes on the substrate. The experimental results show that the all-metal electrode flexible DSSC has almost the same open-circuit voltage as the traditional DSSC with FTO. The schematic diagram and physical drawing are shown in Figure 1.
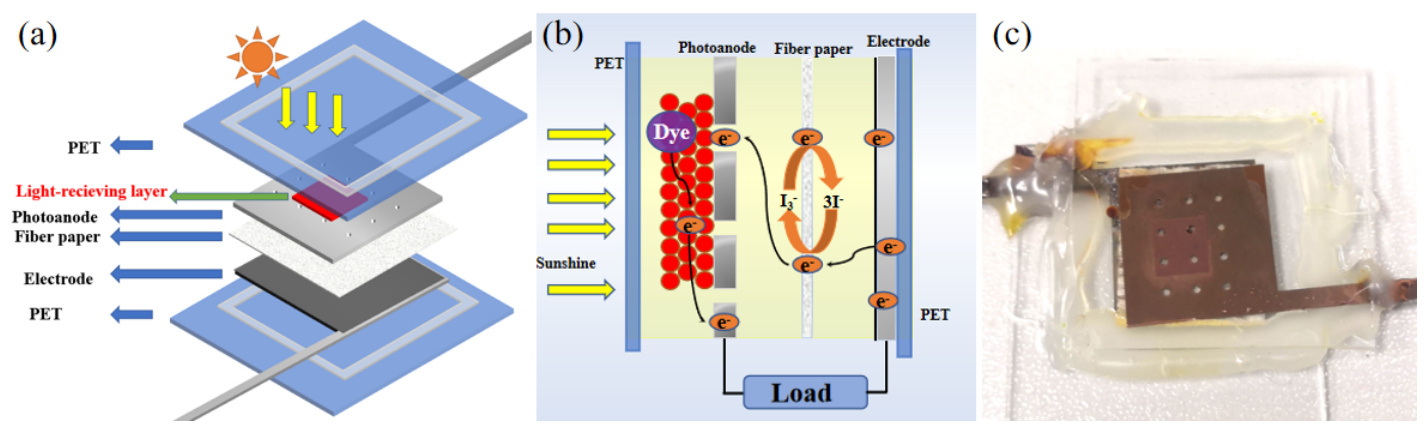

Figure 1. (a) Schematic diagram. A light-receiving layer is prepared on the outside of a metal electrode with small holes to form a photoanode; Fiber paper serves as an insulator and an electrolyte container; a platinum black film is prepared on a metal electrode to form the counter electrode; the battery is packaged with PET and injected with electrolyte. (b) Photoelectric conversion diagram. (c) Physical drawing.

\section{Experiments}

\subsection{Experimental Materials}

The 304 stainless-steel foil was customized by Hengrui company, and Titanium foil was customized by Yiyuan. Dust-free paper, PET, dust-free cloth, tweezers, glass plate, glass rod, scissors, hot-melt glue gun, aluminum foil paper, fresh-keeping film, 3M Scotch tape, scraper, screen printing, and other tools were also used. In addition, the drugs used were as follows: $\mathrm{AE}$ (absolute ethanol, $>99 \%), \mathrm{TiO}_{2}(>99 \%), \mathrm{Pt}(>99 \%), \mathrm{I}_{2}(>99 \%), \mathrm{LiI}(>99 \%)$, PMII (>99\%), TBP (>99\%), GuSCN (>99\%), N719 (>99\%).

\subsection{Preparation of Photoanode}

First, holes were punched in the stainless-steel foil, according to a certain density and size, then cleaned up and placed on a glass plate to dry. The scotch tape was glued to the dry foil, leaving a $5 \times 5 \mathrm{~mm}^{2}$ square surface which included four holes. $\mathrm{TiO}_{2}$ slurry was scraped on the foil carefully with a glass rod. The foil sample was sent into a muffle furnace for heating and taken out after natural cooling. The $\mathrm{TiO}_{2}$ was dyed with $0.4 \mathrm{mmol} / \mathrm{L} \mathrm{N719}$ solution dissolved in ethanol. After $24 \mathrm{~h}$, the foil with $\mathrm{TiO}_{2}$ was taken out and cleaned with $\mathrm{AE}$, and then air-dried. The flowchart is shown in Figure 2. The preparation steps of titanium photoanode and non-drilling FTO photoanode are the same as above.

\subsection{Preparation of Counter Electrode}

The clean stainless-steel foil was placed and fixed on a screen-printing table with a 200-mesh screen. Then it was scraped with chloroplatinic acid slurry. After a few minutes, the foil with chloroplatinic acid film was placed in a heating boat and put into a tubular annealing furnace. The temperature was increased to $400{ }^{\circ} \mathrm{C}$ for $30 \mathrm{~min}$. The CE could then be used after natural cooling. The preparation of FTO CE is the same as the above steps. 

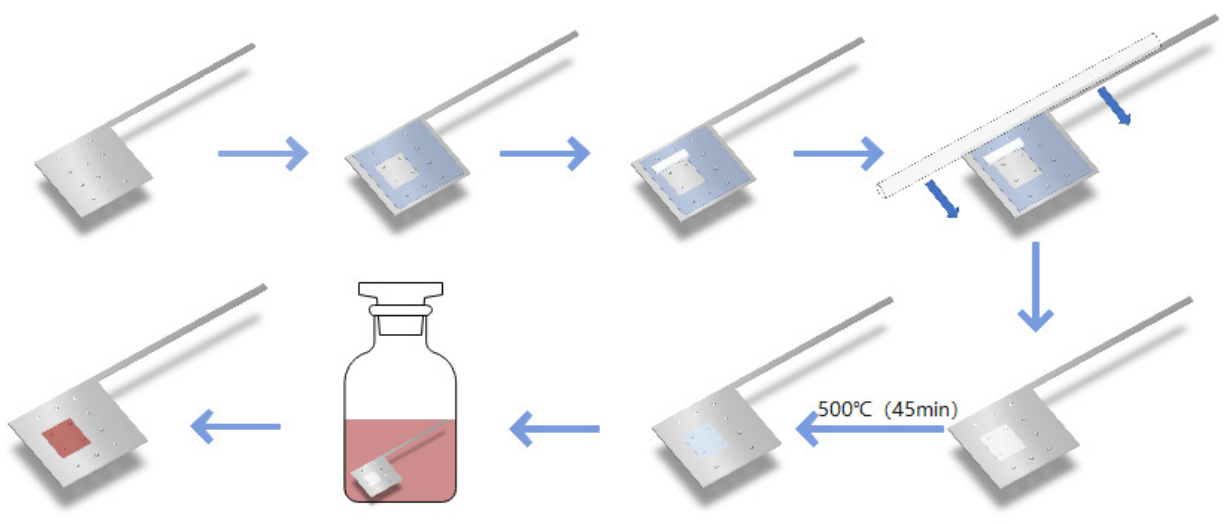

Figure 2. Photoanode preparation process.

\subsection{Photosensitizer and Electrolyte Preparation}

(1) Photosensitizer preparation: each $100 \mathrm{~mL}$ of photosensitizer contained $47.5 \mathrm{mg}$ dye N719 dissolved in AE. After the proportioning, the solution was poured into a beaker sealed with plastic wrap film and equipped with a magnetic rotor. The solution was stirred with a magnetic stirrer for $30 \mathrm{~min}$.

(2) Electrolyte preparation: each $100 \mathrm{~mL}$ of electrolyte contained $\mathrm{I}_{2} 1.523 \mathrm{~g}$, LiI $8.031 \mathrm{~g}$, GuSCN $0.708 \mathrm{~g}$, TBP $6.761 \mathrm{~g}$, and PMII $7.563 \mathrm{~g}$. All of them were dissolved by acetonitrile, then the acetonitrile solution was poured into a clean beaker to stir for $20 \mathrm{~min}$ with a magnetic stirrer $[10,38]$.

\subsection{Device Assembly}

First, the PET was cut into $3 \times 3 \mathrm{~cm}^{2}$, cleaned with $\mathrm{AE}$, and placed on a glass plate. A CE was placed on PET in the lower left corner with the platinum side facing up. Then, the $C E$ was covered completely with a piece of $1.8 \times 1.8 \mathrm{~cm}^{2}$ dust-free paper. Finally, the photoanode and another piece of PET were placed on top of them one after the other. The battery was sealed with a hot-melt glue gun. A syringe was used to insert the electrolyte through the small hole reserved on the PET, and the hole was sealed at the end.

\subsection{Characterization}

The morphology of $\mathrm{TiO}_{2}$ on stainless steel and titanium sheet was observed with a positive metallographic microscope (BX51M, OLYMPUS, Tokyo, Japan). The two-dimensional and three-dimensional morphology of $\mathrm{TiO}_{2}$ surface were obtained by an atomic force microscope (DSM14049BF-1, Bruker, Billerica, MA, USA). The 100 $\times$ and 500 $\times$ magnified images of $\mathrm{TiO}_{2}$ films were obtained by scanning electron microscope SEM (TESCAN, Brno, Czech Republic). The J-V curve of DSSC was obtained through a combination of OAI solar simulator (LCSS150, Zolix, Beijing, China) and KEITHLEY2400 digital source meter (Oriel 94023A, Newport). The external quantum efficiency of DSSC was obtained through the quantum efficiency test system (PEC-S20, Gifu, Japan). The UV-VIS spectrum of DSSC was obtained by UV-VIS Spectrometer (UV-24500, Avantes, Appeldom, The Netherlands).

\section{Results and Discussion}

First, the experiments confirmed that the design goal of an all-metal electrode without FTO/ITO can be realized via this new structure, which has an external light-receiving layer and small holes on the photoanode. Moreover, the application of PET and metal foils also ensure the flexibility of DSSC. The measurement data of the samples show that in order to obtain sufficient output, the combination of electrode materials and the preparation process of the $\mathrm{TiO}_{2}$ layer must be handled carefully. 


\subsection{Design of Holes on Photoanode}

The small holes reserved on the photoanode are an important structure to ensure the penetration of electrolyte and the continued progress of the redox reaction. When the aperture is too large, it is obvious that the area coated with $\mathrm{TiO}_{2}$ on the photoanode will decrease, resulting in the loss of the light-receiving layer. Figure 3 shows the dimensions of the two verified holes.
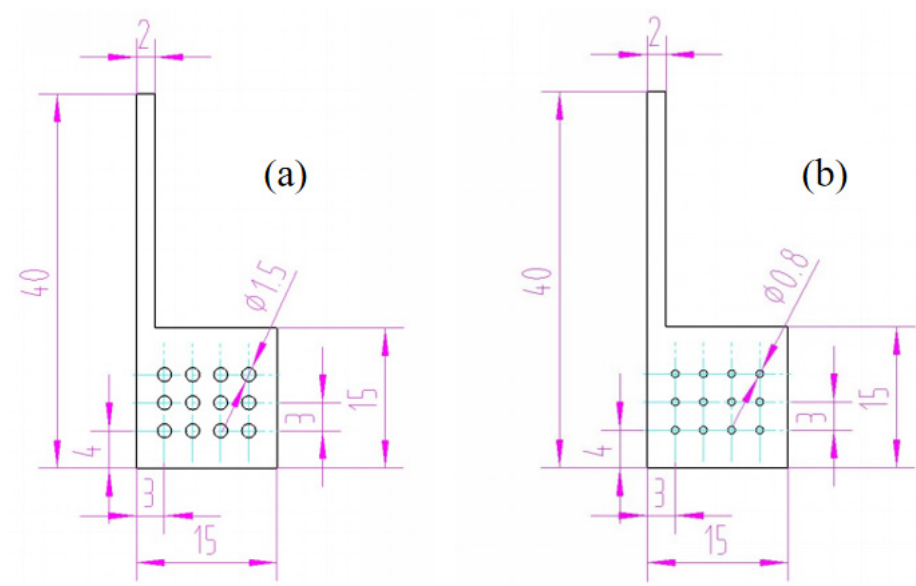

Figure 3. Drawing of holes on the photoanode. (a) holes in $\phi 1.5 \mathrm{~mm}$; (b) holes in $\phi 0.8 \mathrm{~mm}$. The units of the figures are in millimeters.

During the scraping of $\mathrm{TiO}_{2}$, Scotch tape was used to surround a $5 \mathrm{~mm} \times 5 \mathrm{~mm}$ area covering four small holes on the electrode. For the first type shown in Figure $3 a$, the area of the light-receiving layer is $17.93 \mathrm{~mm}^{2}$, accounting for $72 \%$ of the whole area of $25 \mathrm{~mm}^{2}$; for the other type shown in Figure $3 b$, that is $22.99 \mathrm{~mm}^{2}$, accounting for $92 \%$ of the entire area. The area ratio of these two types is $0.78: 1$.

The stainless-steel photoanodes and titanium photoanodes with these different apertures have been assembled in DSSC, respectively. By comparing the J-V characteristic curves of the four samples, it is found that the hole size has no influence on the open-circuit voltage. On the other hand, whether it is titanium or stainless steel, the current density of the battery with $\phi 1.5 \mathrm{~mm}$ holes is about $81 \%$ of that with $\phi 0.8 \mathrm{~mm}$ holes. Looking into the light-receiving area ratio $0.78: 1$, it is obvious that the two ratios are very close. Consequently, we can judge that the diffusion of ions in electrolyte does not require a large pore size. Therefore, the density and size of these holes should be limited as much as possible to obtain a larger light-receiving layer area.

\subsection{Influence of Heating Rate}

A muffle furnace with a controllable temperature curve was used, and two groups of electrodes with different heating rates were set for experiments. After scraping $\mathrm{TiO}_{2}$ paste, the stainless-steel electrode of group A rose to $500^{\circ} \mathrm{C}$ from room temperature within $45 \mathrm{~min}$, and the temperature of group $\mathrm{B}$ rose within $30 \mathrm{~min}$. After natural cooling, the electrode was taken out, and the $\mathrm{TiO}_{2}$ was transferred to the metallographic microscope. Figure 4a,c shows these patterns of the group A electrode with 100 times and 500 times magnification, respectively. Figure $4 \mathrm{~b}, \mathrm{~d}$ shows those of group B. It can be intuitively observed that when the temperature is raised faster, a large number of cracks and defects appear on the surface of the group B electrode, and the intact film area accounts for only about $60 \%$. Compared with group $\mathrm{A}$, it can be observed that when the heating rate is slow, the surface of $\mathrm{TiO}_{2}$ can be relatively flat, and the texture can be consistent with that of stainless steel. 

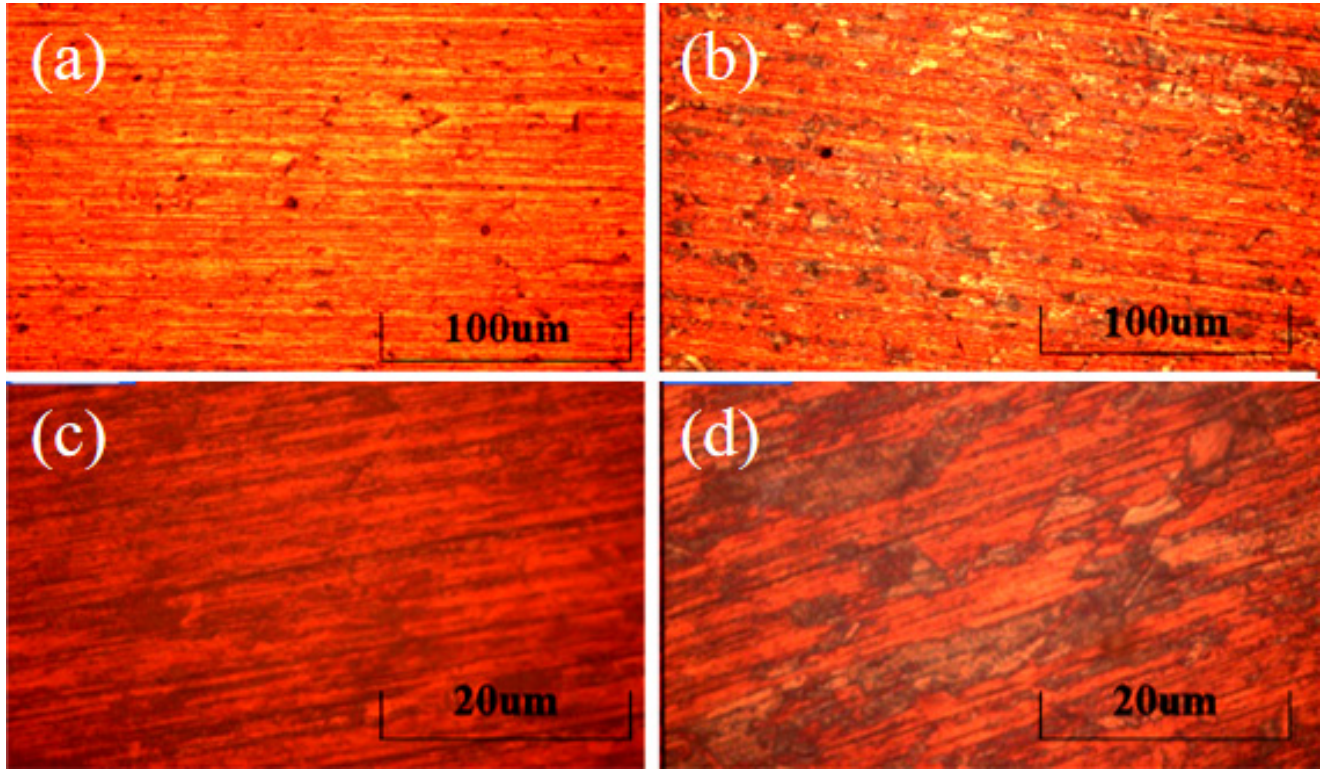

Figure 4. The morphology of $\mathrm{TiO}_{2}$ film through a $\mathrm{BX} 51 \mathrm{M}$ microscope. (a) Group $\mathrm{A}$, the heating rate is $11^{\circ} \mathrm{C} / \mathrm{min}$ and lasts $45 \mathrm{~min}, 100$ times magnification. (b) Group $\mathrm{B}$, the heating rate is $16^{\circ} \mathrm{C} / \mathrm{min}$ and lasts $30 \mathrm{~min}, 100$ times magnification. (c) Group A with 500 times magnification. (d) Group B with 500 times magnification.

Two sets of electrodes were used to assemble DSSC, respectively. The solar energy test system was used under AM1.5 standard sunlight. It can be seen from Figure 5 that when the heating rate of the prepared electrode is $16^{\circ} \mathrm{C} / \mathrm{min}$ (Group B), the short-circuit current density is only half of the case of $11^{\circ} \mathrm{C} / \mathrm{min}$ (Group A). According to the morphology of the electrode surface, it can be inferred that the large-area damage caused by the heating rate to the film cannot be ignored, which will damage the photoelectric conversion ability.

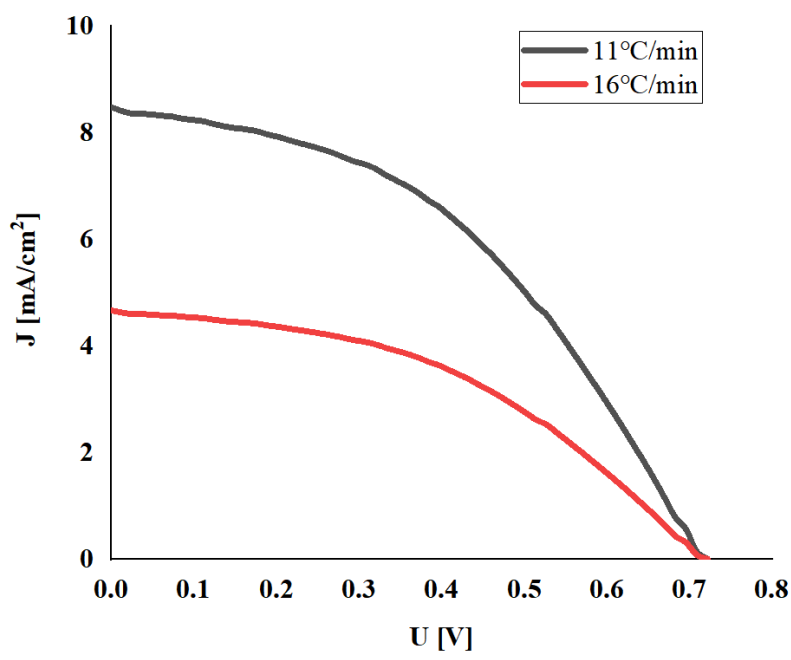

Figure 5. J-V Characteristics of DSSC with $\mathrm{TiO}_{2}$ film prepared at different heating rates.

\subsection{Comparison between Metal Photoanode Battery and FTO Electrode Batteries}

Four groups of control experiments were set, as shown in Table 1. The experimental procedure was the same as those described in Section 2, only the different electrodes were assembled into four groups of batteries. It is worth noting that the photoanode light-receiving layer of the stainless-steel substrate faced the outside of the battery; on the contrary, that of the FTO substrate faced the inside. 
Table 1. Four experiment groups with different electrode combination.

\begin{tabular}{ccc}
\hline Experiment Group & Photoanode Base Material & Counter Electrode Base Material \\
\hline A (Steel/Steel, SS) & Stainless steel & Stainless steel \\
B (Steel/FTO, SF) & Stainless steel & FTO \\
C (FTO/Steel, FS) & FTO & Stainless steel \\
D (FTO/FTO, FF $)$ & FTO & FTO \\
\hline
\end{tabular}

The J-V characteristics of the four groups are shown in Figure 6a, and the performance indexes are shown in Table 2. The results imply that the difference of photoanode substrate is the main factor that causes the photoelectric conversion ability of the battery. The difference in the short-circuit current density is the most obvious. The short-circuit current densities of group A(SS) and B(SF) were $3.8 \mathrm{~mA} / \mathrm{cm}^{2}$ and $5.2 \mathrm{~mA} / \mathrm{cm}^{2}$, respectively. FTO was used as the photoanode substrate in group $\mathrm{C}(\mathrm{FS})$ and $\mathrm{D}(\mathrm{FF})$, and the short-circuit current density reached $17.0 \mathrm{~mA} / \mathrm{cm}^{2}$ and $18.2 \mathrm{~mA} / \mathrm{cm}^{2}$, respectively. The difference is nearly four-fold. The reasons for the huge difference should be diverse. First, the most likely problem is the interface. The interface between the metal photoanode and $\mathrm{TiO}_{2}$ may be not well-combined, and the work function may not match very well. Secondly, the quality of the $\mathrm{TiO} 2$ film may be not good enough. Thirdly, there is leakage. Some pretreatment on the surface of the metal substrate may further improve the conversion efficiency.

(a)

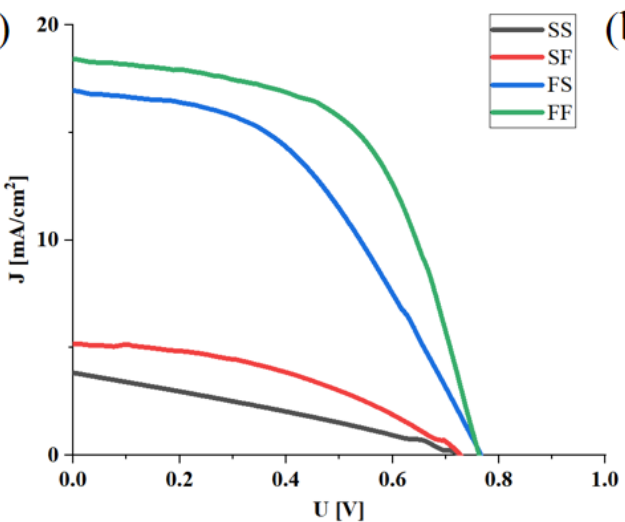

(b)

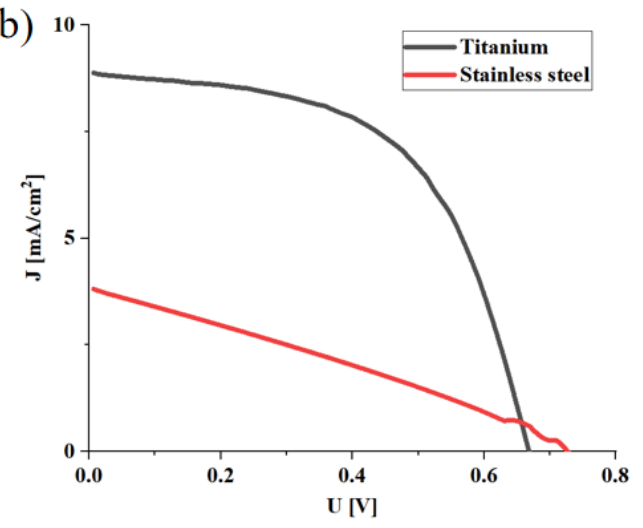

Figure 6. (a) J-V Characteristics curve of cells assembled with four different electrode combinations, (b) J-V characteristics curve of stainless-steel counter electrode cells assembled with two different metal photoanodes.

Table 2. Performance of different electrode combination batteries.

\begin{tabular}{ccccc}
\hline Electrode Combination & $\begin{array}{c}\text { Jsc } \\
\left(\mathbf{m A} / \mathbf{c m}^{\mathbf{2}}\right)\end{array}$ & $\begin{array}{l}\text { Voc } \\
\mathbf{( V )}\end{array}$ & $\begin{array}{c}\text { FF } \\
\mathbf{( \% )}\end{array}$ & $\begin{array}{c}\boldsymbol{\eta} \\
\mathbf{( \% )}\end{array}$ \\
\hline A (Steel/Steel) & 3.8 & 0.73 & 30.1 & 0.83 \\
B (Steel/FTO) & 5.2 & 0.73 & 35.0 & 1.32 \\
C (FTO/Steel) & 17.0 & 0.76 & 55.0 & 7.11 \\
D (FTO/FTO) & 18.2 & 0.76 & 59.7 & 8.26 \\
\hline
\end{tabular}

At the same time, it can be found that there is almost no influence on the change of the substrate of the $\mathrm{CE}$, though it is undeniable that FTO still has a slight advantage in the current characteristics as a CE.

Another key indicator of the battery, the open-circuit voltage, can also be seen in Figure 6a and Table 2. These open-circuit voltages of the four groups of batteries A, B, C, and $\mathrm{D}$ are $0.73 \mathrm{~V}, 0.73 \mathrm{~V}, 0.76 \mathrm{~V}$ and $0.76 \mathrm{~V}$, respectively. They are very similar.

In addition, we have further studied the reasons for the large differences in the short-circuit current density of the four groups. Figure 7a,c shows the morphology of 
$\mathrm{TiO}_{2}$ sintered on FTO, and Figure $7 \mathrm{~b}$,d shows that of the stainless-steel electrode under a scanning electron microscope. Firstly, it can be found from Figure $7 \mathrm{~b}$ that using the same method as FTO, the porous titanium dioxide layer was successfully prepared on the stainless-steel electrode; however, comparing Figure $7 \mathrm{a}, \mathrm{b}$, the coverage area of the porous titanium dioxide layer prepared on FTO is denser. In Figure $7 c$, the $\mathrm{TiO}_{2}$ layer uniformly covers the FTO surface, and the porous structure is relatively uniform, but there are still some irregularities, which may be caused by the uneven particle size of $\mathrm{P}_{2} 5-\mathrm{TiO}_{2}$. In Figure $7 d$, the irregularity of the titanium dioxide layer on the stainless steel is clear and the caves are deeper.
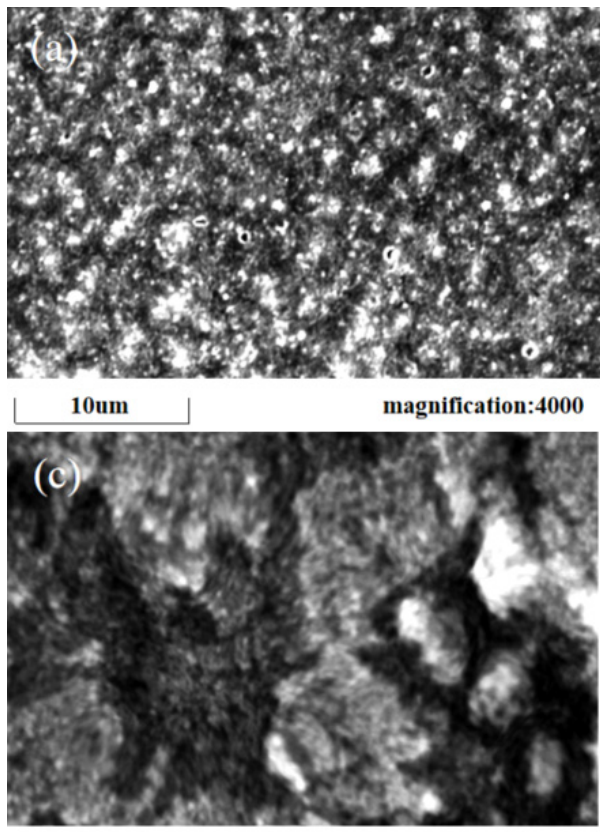

$200 \mathrm{~nm}$

magnification:200000
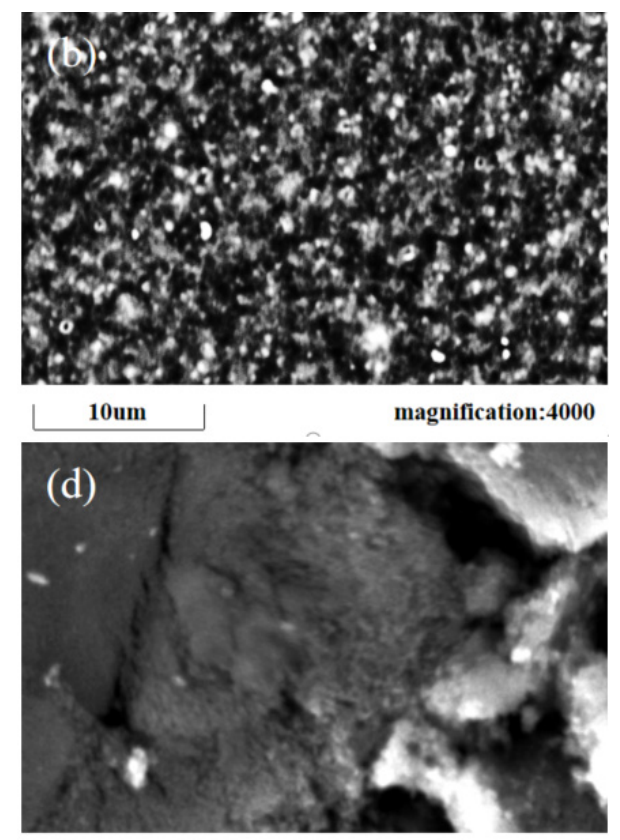

$200 \mathrm{~nm}$

magnification:200000

Figure 7. SEM of $\mathrm{TiO}_{2}$ films on different electrode surfaces: (a) FTO surface, 4000 times magnification; (b) stainless steel surface, 4000 times magnification; (c) FTO surface, 200,000 times magnification; (d) stainless steel surface, 200,000 times magnification.

Figure 8 shows the AFM characterization of the $\mathrm{TiO}_{2}$ layer on FTO and stainless steel, respectively. It can be observed that porous $\mathrm{TiO}_{2}$ on FTO has more details and is intensive, while $\mathrm{TiO}_{2}$ on stainless steel is smoother, except for some burrs. The average roughness $\mathrm{Ra}$ of the film on FTO is $0.0182 \mu \mathrm{m}$, and the average roughness Ra of the film on stainless steel is $0.0403 \mu \mathrm{m}$. The height difference of the stainless-steel surface is larger. It can also be seen from Figure $8 \mathrm{~d}$ that the $\mathrm{TiO}_{2}$ layer on the stainless-steel surface has a large wave shape. Combined with the metallographic microscope diagram, it implies that the fluctuation of the film surface is caused by the texture of the metal surface, which is also the reason for its large maximum roughness.

\subsection{Influence of Different Metal Electrodes}

Titanium foil is the most suitable metal electrode material for DSSC, with the exception of stainless steel. The difference of the J-V curve between the titanium photoanode dyesensitized battery and the stainless-steel photoanode dye-sensitized battery is shown in Figure $6 \mathrm{~b}$. In these batteries, stainless-steel electrodes prepared with platinum black are used as the CE.

It can be seen that the titanium electrode adopting this new structure has remarkable photoelectric conversion ability. In the case of the titanium photoanode, the open-circuit voltage decreases slightly, but the short-circuit current density and filling factor have been 
significantly improved. The short-circuit current density can reach $8.87 \mathrm{~mA} / \mathrm{cm}^{2}$ which is 2.3 times that of stainless steel.
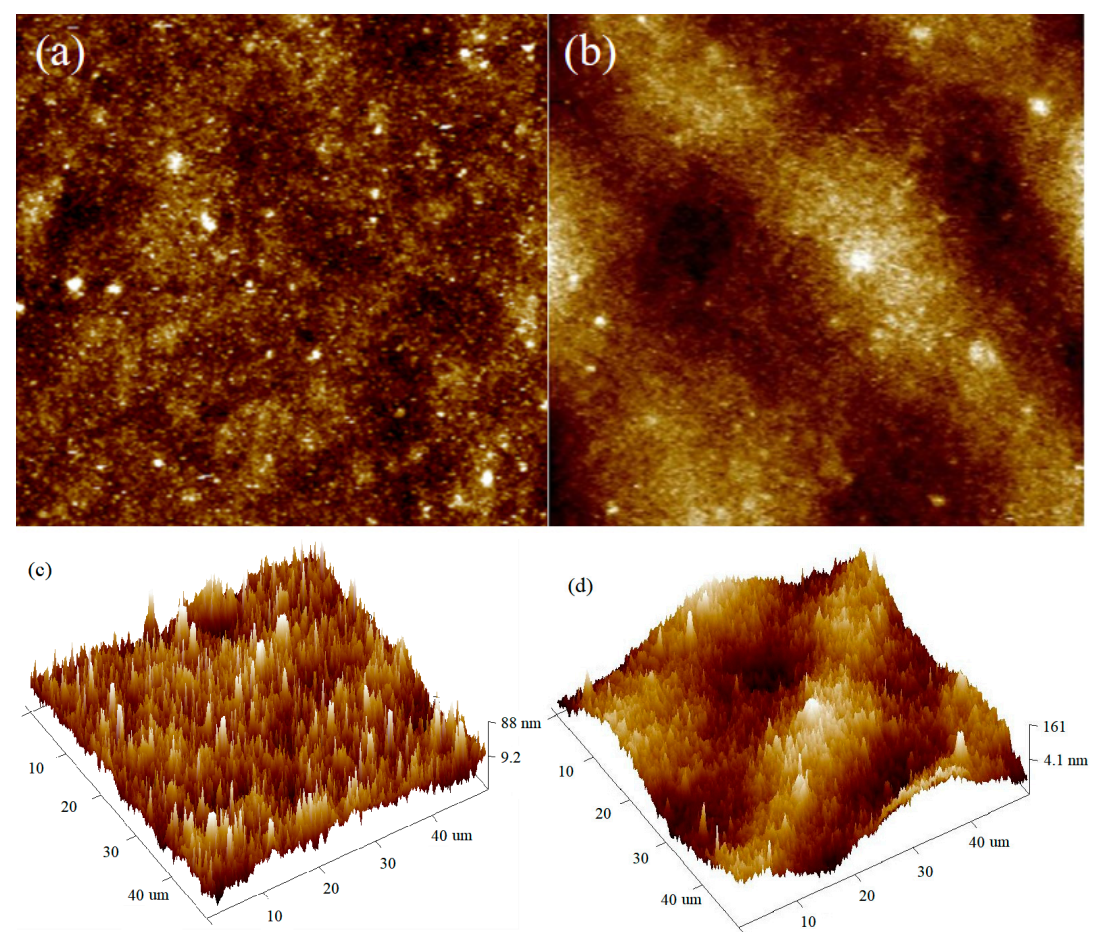

Figure 8. $\mathrm{AFM}$ of $\mathrm{TiO}_{2}$ thin film on different electrode surfaces: (a) $\mathrm{TiO}_{2}$ film morphology on FTO; (b) $\mathrm{TiO}_{2}$ film morphology on stainless steel; (c) AFM 3D diagram on FTO; (d) AFM 3D diagram on stainless steel.

\section{Conclusions}

In order to eliminate the restriction of FTO/ITO in DSSC production, a new DSSC structure with all-metal electrodes and electrode preparation process is studied in this paper. First, our research shows that if the electrolyte has sufficient fluidity, the density and size of the holes should be restricted as much as possible to obtain a larger light-receiving layer area. Second, the heating rate for preparing $\mathrm{TiO}_{2}$ film should not be too fast. The short-circuit current density at a heating rate of $11^{\circ} \mathrm{C} / \mathrm{min}$ is twice that of a heating rate of $16^{\circ} \mathrm{C} / \mathrm{min}$. Third, the metal electrodes have little influence on the open-circuit voltage of DSSC. In the case of a totally stainless-steel electrode, the open-circuit voltage can be $0.73 \mathrm{~V}$, which is almost same as a traditional batterie. Moreover, the photoanode substrate material and the morphology of $\mathrm{TiO}_{2}$ film are key factors of short-circuit current density. When the titanium is used as a photoanode substrate, and there is no need for a complicated process and any additional treatment, the photoelectric conversion efficiency can reach $3.86 \%$. This is 4.65 times higher than stainless steel. At the same time, the short-circuit current density can reach $8.87 \mathrm{~mA} / \mathrm{cm}^{2}$, and the filling factor can reach nearly $57 \%$. In summary, it can be concluded that an all-metal electrode structure with an external light-receiving layer and small holes on the photoanode can be used for DSSC without any FTO/ITO.

Author Contributions: J.Y. designed this project; Y.L. and X.Y. carried out most of the experiments and data analysis; Z.Z. and G.C. performed part of the experiments and helped with discussions during manuscript preparation; Z.Y., F.C. and L.L. gave suggestions on project management and conducted helpful discussions on the experimental results. All authors have read and agreed to the published version of the manuscript.

Funding: This research was supported by the National Key R\&D Program of China (Grant No. 2018YFB0407100). 
Conflicts of Interest: The authors declare no conflict of interest.

\section{References}

1. Grätzel, M. Photovoltaic performance and long-term stability of dye-sensitized meosocopic solar cells. Comptes Rendus Chim. 2006, 9, 578-583. [CrossRef]

2. Liao, J.Y.; Lei, B.X.; Chen, H.Y.; Kuang, D.B.; Su, C.Y. Oriented hierarchical single crystalline anatase $\mathrm{TiO}_{2}$ nanowire arrays on Ti-foil substrate for efficient flexible dye-sensitized solar cells. Energy Environ. Sci. 2012, 5, 5750-5757. [CrossRef]

3. Kang, M.G.; Park, N.G.; Ryu, K.S.; Chang, S.H.; Kim, K.J. A 4.2\% efficient flexible dye-sensitized $\mathrm{TiO}_{2}$ solar cells using stainless steel substrate. Sol. Energy Mater. Sol. Cells 2006, 90, 574-581. [CrossRef]

4. Orhan, E.; Gokcen, M.; Taran, S. Effect of the photoanode fabrication condition, electrolyte type and illumination type on dye-sensitized solar cells performance. Bull. Mater. Sci. 2021, 44, 60. [CrossRef]

5. Cha, H.L.; Seok, S.; Kim, H.J. Towards achieving improved efficiency using newly designed dye-sensitized solar cell devices engineered with dye-anchored counter electrodes. J. Ind. Eng. Chem. 2021, 99, 117-125. [CrossRef]

6. Baby, R.; Nixon, P.D.; Kumar, N.M. A comprehensive review of dye-sensitized solar cell optimal fabrication conditions, natural dye selection, and application-based future perspectives. Environ. Sci. Pollut. Res. 2021, 29, 371-404. [CrossRef] [PubMed]

7. Rozman, M.; Sygkridou, D.; Godec, R.F.; Stathatos, E.; Bren, U. Novel geometric approach for photosensor construction based on dye-sensitization of $\mathrm{TiO}_{2}$ nanoparticles on stainless steel. Sens. Actuators A Phys. 2019, 295, 51-58. [CrossRef]

8. Dissanayake, M.A.K.L.; Kumari, J.M.K.W.; Senadeera, G.K.R.; Weerasinghe, T.J.; Anawar, H. A low-cost, vein graphite/tin oxide nanoparticles based composite counter electrode for efficient dye-sensitized solar cells. Mater. Sci. Eng. 2021, $273,115440$. [CrossRef]

9. Chai, Z.S.; Gu, J.W.; Khan, J.; Yuan, Y.F.; Du, L.H.; Yu, X.; Wu, M.M.; Mai, W.J. High-performance flexible dye-sensitized solar cells by using hierarchical anatase $\mathrm{TiO}_{2}$ nanowire arrays. RSC Adv. 2015, 5, 88052-88058. [CrossRef]

10. Liu, W.W.; Lu, H.; Zhang, M.; Guo, M. Controllable preparation of $\mathrm{TiO}_{2}$ nanowire arrays on titanium mesh for flexible dyesensitized solar cells. Appl. Surf. Sci. 2015, 347, 214-223. [CrossRef]

11. Agrawal, A.; Siddiqui, S.A.; Soni, A.; Khandelwal, K.; Sharma, G.D. Performance analysis of $\mathrm{TiO}_{2}$ based dye sensitized solar cell prepared by screen printing and doctor blade deposition techniques. Sol. Energy 2021, 226, 9-19. [CrossRef]

12. Ooyama, Y.; Harima, Y. Molecular Designs and Syntheses of Organic Dyes for Dye-Sensitized Solar Cells. Eur. J. Org. Chem. 2009, 2009, 2903-2934. [CrossRef]

13. Hamidian, K.; Rahimi, R.; Hosseini-Kharat, M. Development of the molecular engineering of disazo dye sensitizers and TiO 2 semiconductor surface to improve the power conversion efficiency of dye-sensitized solar cells. J. Photochem. Photobiol. A Chem. 2021, 418, 113408. [CrossRef]

14. Acchutharaman, K.R.; Santhosh, N.; Daniel, R.I. Enhanced electron harvesting in next generation solar cells by employing TiO 2 nanoparticles prepared through hydrolysis catalytic process. Ceram. Int. 2021, 47, 21263-21270. [CrossRef]

15. Yamaguchi, T.; Tobe, N.; Matsumoto, D.; Arakawa, H. Highly efficient plastic substrate dye-sensitized solar cells using a compression method for preparation of $\mathrm{TiO}_{2}$ photoelectrodes. Chem. Commun. 2007, 45, 4767-4769. [CrossRef]

16. Raguram, T.; Rajni, K.S. Effect of Ni doping on the characterization of $\mathrm{TiO}_{2}$ nanoparticles for DSSC applications. J. Mater. Sci. Mater. Electron. 2021, 32, 18264-18281. [CrossRef]

17. Mustafa, M.N.; Azhari, N.A.; Sulaiman, Y.R. Reduced graphene oxide-titanium dioxide compact layer prepared via electrodeposition for enhanced performance of dye-sensitized solar cells. Opt. Mater. 2021, 120, 111475. [CrossRef]

18. Baiju, K.G.; Murali, B.; Rao, R.S.; Jayanarayanan, K.; Kumaresan, D. Heat sink assisted elevated temperature sintering process of $\mathrm{TiO}_{2}$ on polymer substrates for producing high performance flexible dye-sensitized solar cells. Chem. Eng. Process. Process. Intensif. 2020, 149, 107817. [CrossRef]

19. Huang, G.L.; Qiao, X.D.; Liu, Y.Y.; Lei, B.X.; Sun, W.; Sun, Z.F. Facile synthesis of three-dimensional interweaved titania nanotape networks as dye-sensitized solar cell photoanode. Thin Solid Film. 2016, 615, 97-102. [CrossRef]

20. Muqoyyanah, A.B.S.; Mohamed, A. Effects of $\mathrm{TiO}_{2}$ phase and nanostructures as photoanode on the performance of dye-sensitized solar cells. Bull. Mater. Sci. 2021, 44, 10. [CrossRef]

21. Han, H.G.; Weerasinghe, H.C.; Kim, K.M.; Kim, J.S.; Cheng, Y.B.; Jones, D.J.; Holmes, A.B.; Kwon, T.H. Ultrafast Fabrication of Flexible Dye-Sensitized Solar Cells by Ultrasonic Spray-Coating Technology. Sci. Rep. 2015, 5, 14645. [CrossRef]

22. Wang, Y.L.; Cheng, P.F.; Feng, C.H.; Zhang, H.; Zhao, W.B. High performance flexible dye-sensitized solar cells base on multiple functional optimizations. Sol. Energy 2019, 180, 423-428. [CrossRef]

23. Min, K.W.; Chao, S.M.; Yu, M.T.; Ho, C.T.; Chen, P.R.; Wu, T.L. Graphene-TiO2 for scattering layer in photoanodes of dye-sensitized solar cell. Mod. Phys. Lett. B 2021, 35, 2141005. [CrossRef]

24. Zhu, K.; Neale, N.R.; Miedaner, A.; Frank, A.J. Enhanced charge-collection efficiencies and light scattering in dye-sensitized solar cells using oriented $\mathrm{TiO}_{2}$ nanotubes arrays. Nano Lett. 2007, 7, 69-74. [CrossRef] [PubMed]

25. Roy, P.; Kim, D.; Lee, K.; Spiecker, E.; Schmuki, P. TiO 2 nanotubes and their application in dye-sensitized solar cells. Nanoscale 2010, 3, 45-59. [CrossRef] [PubMed]

26. Muhammad, S.A.; Pandey, A.K.; Nasrudin, A.R. Effect of Nanodiamonds on the Optoelectronic Properties of TiO 2 Photoanode in Dye-Sensitized Solar Cell. Arab. J. Sci. Eng. 2018, 43, 3515-3519. [CrossRef] 
27. Pandey, A.K.; Muhammad, S.A.; Mahdi, A.; Nasrudin, A.R. Improved electron density through hetero-junction binary sensitized $\mathrm{TiO}_{2} / \mathrm{CdTe} / \mathrm{D} 719$ system as photoanode for dye sensitized solar cell. Phys. E Low. Dimens. Syst. Nanostruct. 2018, 101, 139-143. [CrossRef]

28. Wei, D. Dye Sensitized Solar Cells. Int. J. Mol. Sci. 2010, 11, 1103-1113. [CrossRef]

29. Huang, K.C.; Wang, Y.C.; Chen, P.Y.; Lai, Y.H.; Huang, J.H.; Chen, Y.H.; Dong, R.X.; Chu, C.W.; Lin, J.J.; Ho, K.C. High performance dye-sensitized solar cells based on platinum nanoparticle/multi-wall carbon nanotube counter electrodes: The role of annealing. J. Power Sources 2012, 203, 274-281. [CrossRef]

30. Martinson, A.B.F.; Elam, J.W.; Hupp, J.T.; Pellin, M.J. Radial electron collection in dye-sensitized solar cells. Nano Lett. 2008, 8 , 2183-2187. [CrossRef]

31. Mishra, A.; Fischer, M.R.; Buerle, P. Metal-Free Organic Dyes for Dye-Sensitized Solar Cells: From Structure: Property Relationships to Design Rules. Angew. Chem. Int. Ed. 2009, 48, 2474-2499. [CrossRef] [PubMed]

32. Robertson, N. Optimizing dyes for dye-sensitized solar cells. Angew. Chem. Int. Ed. 2006, 45, 2338-2345. [CrossRef] [PubMed]

33. Ramli, M.A.; Mawarnis, E.R.; Umar, M.I.A. Charge transfer uplift in dye-sensitized solar cells using fibrous nanocrystals of platinum-based bimetallic counter electrodes. Surf. Interfaces 2021, 26, 101311. [CrossRef]

34. Fayaza, H.; Muhammad, S.A.; Pandeyc, A.K.; Nasrudin, A.R.; Tyagi, V.V. A Novel nanodiamond/Zinc nanocomposite as potential counter electrode for flexible dye sensitized solar cell. Sol. Energy 2020, 197, 1-5. [CrossRef]

35. Lee, C.H.; Lu, M.D.; Guan, Q.Z.; Tung, Y.L.; Tsai, S.Y.; Lin, F.M. Thickness-controllable textured $\mathrm{TiO}_{2}$ underlayer for a flexible dye-sensitized solar cell sub-module. Mater. Res. Express 2014, 1, 025503. [CrossRef]

36. Sabet, M.; Jahangiri, $\mathrm{H}$. Growth of $\mathrm{TiO}_{2}$ nanotubes on the Ti foil by anodizing method used in the flexible dye-sensitized solar cell in presence of three counter electrodes. J. Mater. Sci. Mater. Electron. 2017, 28, 6566-6571. [CrossRef]

37. Li, Z.D.; Yang, H.; Zhang, L.F.; Liu, R.H.; Zhou, Y. Stainless steel mesh-supported three-dimensional hierarchical $\mathrm{SnO}_{2} / \mathrm{Zn}_{2} \mathrm{SnO}_{4}$ composite for the applications in solar cell, gas sensor, and photocatalysis. Appl. Surf. Sci. 2020, 502, 144113. [CrossRef]

38. Siti, M.M.Y.; Wan, Z.N.Y. Binary Ionic Liquid Electrolyte for Dye-Sensitized Solar Cells. Procedia Eng. 2016, 148, 100-105. [CrossRef] 